\title{
THE CONCEPT OF REGULATED USE OF NATURAL HERITAGE SITES INCLUDED IN THE TOURIST CLUSTER: A RUSSIAN CAVES CASE STUDY
}

\author{
A. N. Polukhina ${ }^{1, C}$, Yu. S. Lyakhnitsky², and V. V. Lezhnin ${ }^{1}$
}

\begin{abstract}
The rationale for our research arises from non-regulated use of caves for commercial and sightseeing purposes, which can significantly damage objects of cultural heritage or result in their complete destruction. In this respect, our paper aims to define the factors necessary for the development of nature preserves and tourist centers that provide for the preservation of caves that are properly maintained and used by the public. The paper employs a multidisciplinary approach based on inter-connections among geological, social, and economic research methods. Geological methods provide complex monitoring of cave environments to ensure that they are not being adversely impacted and remain popular tourist destinations. Social and economic methods allow development of a business model to ensure that their operation is economically sustainable. The authors apply a model of step-by-step formation and development of a cave-related nature preserve and tourist center, exemplified with the case study of the Sablinsky tourist center (Leningrad District), including complex research of the geology, establishment of a nature preserve and tourist unit, development of a self-financing operating plan, cave zoning that allots areas for natural and cultural interpretation, but restricts tourists to special routes, and touristic infrastructure. This paper is intended as a practical guide for promoting the development of domestic tourism in Russian regions and creating new tourist clusters around objects of natural and cultural heritage, while implementing an effective protection of the natural geology and limiting anthropogenic impacts.
\end{abstract}

\section{Introduction}

Since the turn of the $21^{\text {st }}$ century, people have become increasingly interested in nature. This is especially true in the highly industrialized, developed countries. Artificial, urbanized landscapes can no longer provide a satisfying life style for people who need to feel a part of nature now more than ever. This trend has resulted in the global development of tourism focused on outdoor recreation and adventure sport. As a result, there is a growing number of tourists who prefer to spend their vacation in the mountains or woods, thus increasing the anthropogenic pressure on the remaining wilderness areas. Therefore, there is a necessity to extend nature conservation work by increasing the number of nature reserves, wildlife reserves, national parks, and state nature sanctuaries. In the Russian Federation, these processes are hindered by economic challenges. There are cases when specially protected areas are illegally used as commercially profitable tourist attractions. While using nature sanctuaries for tourism seems to have negligible consequences, many sites are under pressure because of the absence of systematic monitoring and many businesses do not realize their role or take responsibility for the preservation of natural and cultural heritage sites.

There are many facts demonstrating illegal use of such specially protected natural areas such as caves. Because they evoke great tourist interest, there is a temptation for caves to be used for commercial purposes. Easy access and short distance from urban centers aggravate the problem. Caves become meeting places for so-called adherents of nonconformist, youth subculture, and radical religious groups. Unfortunately, caves are extremely vulnerable to inadvertent or malicious destruction. Caves are an important element of ecosystems, especially the karst hydrology, and as sources of drinking water. Unique deposits, dating to ancient epochs, have accumulated in caves. They often preserve distinctive remnants of our human ancestors and their tools. Most notable are the priceless discoveries of Paleolithic cave paintings, which are primary masterpieces of early human art. Caves may also preserve paleontological remains of rare or extinct animals that disappeared from the surface of our Earth millions of years ago. In the publics' mind, caves are most commonly associated as a refuge for bats. Among mammals, the order Chiroptera is second only to rodents in the number of species worldwide. For all of these reasons, caves are especially popular tourist destinations.

In England alone, there are over 500 caves used for commercial recreation, while in Russia they are too few. It is not because they are not popular; it is mainly because they are used and facilitated without the proper legal grounds agreed upon with nature preserve authorities and, even worse, without an operating plan and regulations for use. Meanwhile, there are many caves suitable for recreation purposes in the Russian Federation.

Commercialization of specially protected natural areas has a devastating effect on both the environment and social sphere, i.e., local people and their way of life. By now, there has been quite extensive experience of both positive and

${ }^{1}$ Department of Service and Tourism Department, Volga State University of Technology, 424000, Yoshkar-Ola, Pl. Lenina 3, Yoshkar-Ola, Russia)

${ }^{2}$ A. P. Karpinsky Russian Geological Research Institute (VSEGEI) 199106, Sankt-Petersburg, Sredniy Prospect 74, Russia.)

c Corresponding Author: PoluhinaAN@volgatech.net; ann_mari@rambler.ru 
negative impacts of tourism on the social and cultural sphere. The negative impact from intense tourist use of specially protected natural areas is manifested as follows: (1) A shift from the traditional types of economic activity to tourism, due to the fact that tourist industry might bring better income; (2) When dealing with international tourists (mainly the wealthy), locals feel underprivileged, due to their low incomes and unsatisfactory way of life; (3) Local people might experience negative emotions when the tourists visit religious sites without permission granted by the local religious leaders. This is the problem for a number of Russian regions, including Mari El Republic; (4) Locals are driven away from the villages, which are turned into summer residences for city dwellers, due to their intense tourist attraction.

To create a positive impact from tourism, especially in the rural areas of Russia with an extended tourist capacity, like specially-protected natural areas, attention should be paid to the establishment of a tourism cluster. This is also defined by the Federal Target Program "Domestic and inbound tourism development in the Russian Federation (2011-2018)". The tourism cluster was based on so-called core business, i.e., creating a tourist product. We believe that the core tourist product in this case may be the tourist potential of specially-protected natural areas. However, the use of the natural heritage should be implemented extremely carefully. In the remainder of our paper, we will concentrate on the concept of regulated use of natural heritage sites.

\section{Background}

The methodology of the concept of regulated use of national heritage sites is under- developed. The Russian scientist Yu. S. Lyakhnitsky first gave name to the concept, although the history of studies and the practical use of caves has

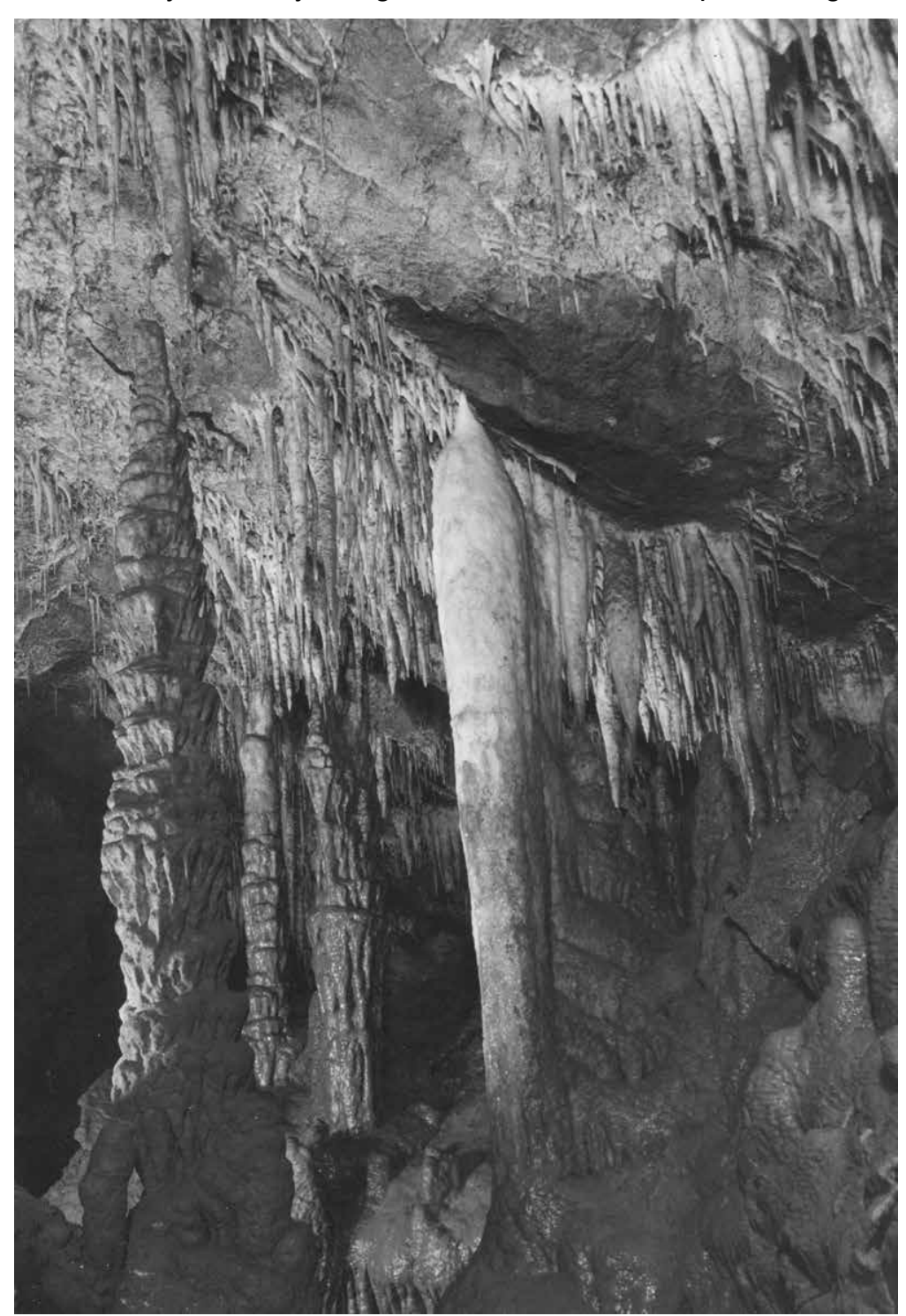

Figure 1. Sinter deposits in the Egyptian Hall of the Labirynthnaya Cave being part of Vorontsovskaya Cave Complex (stalagmites, stalagnates, stalactite). been the focus of scientific attention for more than 100 years. It took decades to research into caves with high scientific value.

In our research, we focus on the negative anthropogenic impact on caves and the counter actions taken to preserve their uniqueness.

Caves represent complex, environmental systems with historically established tunnels. As examples of the negative impact to caves, we can refer to tunneling in Kungur Cave (Lukin and Dorofeev, 1993, Mavlyudov, 2008) and the construction of a solid concrete wall in Karaulnaya-2 and Borodinskaya caves in the 1970s that resulted in degradation caused by perennial icing (Tsykin, 1978, Mavlyudov, 2008).

Extensive tourist visits increase the inflow of carbon dioxide into the cave environment, thus influencing the processes of corrosion and mineral formation in the cave. Among others, this problem was characteristic of Novo-Afonskaya Cave (Dublyansky, 1978) and Mramornaya Cave (Vakhrushev et al., 1999). The cumulative effect of the temperature increase, artificial light, spores, seeds and other biological material, brought in by the visitors, may result in so called "lamp flora" initiation of chlorophyll formation and beginning the growth of moss, fungus, and ferns (Bartoli, 2003).

Lamp flora was found in many caves equipped with artificial lightning. Plant and bacterial communities inhabiting the cave surfaces cause degradation processes, which are especially damaging in caves with Paleolithic paintings. In addition, many types of bacterial flora are potentially pathogenic for humans and may cause allergies (Mazina, 2007).

Unfortunately, many caves with artificial lightning use incandescent-filament lamps as a light source. The artificial light flora is a problem in Kun- 
gur Cave (Naumkin et al., 2004), Vorontsovskaya Cave (Mazina, 2007), and other caves. Some tour guides, bringing visitors to Kungur Cave, initiated the tradition of throwing coins into underground lakes (Rapp, 1999). During early use of Shulgan-Tash Cave for tourism and recreation (prior to more stringent regulations on tour guides and cave security in the 1990s), the graffiti left by visitors covered more than 90 percent of accessible surfaces, significantly damaging the original Paleolithic paintings.

The issues of safe and secure use of caves are not sufficiently discussed in the literature (Maksimovich, 1963, Dublyansky, 1990, Dublyansky and Dublyanskaya, 2004). Legal aspects of cave-based tourist and excursion complexes are formally considered in the works of V.D. Rezvan (Rezvan, 2004). However, not all the cave trails are licensed (Lyakhnitsky, 2002).

The notion of cluster was initially mentioned and analyzed by Michael Porter (2000). According to his definition, a cluster is a "geographic concentration of competing and cooperating companies, service providers and associated institutions in a particular field, linked by commonalities and externalities mutually reinforcing each other" (Porter, 2000, p. 16). Porter stressed that successful cluster development requires strategic development. The cluster formation is mainly aimed at the economic development of the local businesses, based on a long-term (5-10 years) development strategy. The Russian scientist A. Yu. Aleksandrova devised the concept of cluster theory for international tourism development. Based on the existing aspects of tourism industry (i.e., range of inter-industry relations, its fragmented structure, prevalence of small and medium-sized businesses, non-material nature of the tourist product, and others), the author stresses the applicability of the cluster approach for tourism development (Aleksandrova, 2007).

Today, the idea of cluster approach as the model for regional tourism development is extensively discussed in Russian science. This issue is addressed in the works of N.V. Shabalina (2007), A.E. Illarionov (2008), and Yu.P. Kovalev (2011). Particular attention to the formation and development of the strategy for regional tourism development (ethnic, rural) is discussed in the works of A.N. Polukhina $(2010,2012$, Polukhina and Talalaev, 2014). The theory of clusters used for the concept of regulated use of national heritage sites in tourism is understudied and requires further elaboration.

\section{Study Area}

The number of caves used for recreational purposes in Russia is 14. Unfortunately, they are often exploited and without any legal protections or operating agreements obtained from state authorities. An even more serious violation is the absence of research-based development projects with a detailed and regulated visiting plan.

Planning an underground tourist trail should be based on detailed and well-grounded research results: passage morphology, cave roof structure, hydrology, hydrochemistry, mineralogy, microclimatology, microbiology, background radiation, radon dangers, etc. It is evident that speleological engineering is the basis for scientific speleology. No commercial tourist company or speleologist specializing in tourist caves can solve this task on their own.

In the Caucasus, the Urals, and eastern Russia, there are areas with well-developed karst landscape. Also, in the Pinego-Kuloisky district of the Arkhangelsk Region there are a few gypsum caves. In the Caucasus, in Sochi National Park and Logonaki Plateau, there are Vorontsovskaya and Krestik-Turist caves, which are over $10 \mathrm{kms}$ long. In the eastern Sayan mountains there is the largest-in-area cave in the world, known as Oreshnaya Cave, which is about 60 $\mathrm{kms}$ long. On the tributary of the Oredezh River in the Leningrad Region, close to V. Nabokov's residence, there is a unique erosion "Svyataya" (Sacred) cave. It is a picturesque grotto with a small stream. By its size and aesthetic characteristics, it is equal to some karst caves in the Caucasus or the Urals. There are no organized excursions or proper security, even though this pseudo-karst cave is worthy of tourist attention.

Kungur Cave is located in the suburb of Kungur city in the Perm region. It is formed of gypsum and anhydrite of Permian age in the massive Ledyanaya Mountain. This cave is the most popular and the most visited cave in Russia. It has been extensively studied. The first mention of the cave dates to 1703, and it has been the focus of on-site research since 1948. In 1972-1973, a 109-m-long tunnel was excavated into the grotto Vyshka. The gallery leading from Bolshoe (meaning Large), an underground lake, was equipped with electric lighting (Lukin and Dorofeev, 1993). The cave was studied for the purpose of learning more about the microclimatic, hydrological, and hydro-chemical factors of the cave (Kungur Cave, 2005).

The cave and the adjacent territory are included within the historical and nature preserve complex known as "Ledyanaya Mountain and Kungur Ledyanaya Cave" that was established by the edict of the Governor of Perm region No 163, dated 26 June, 2001 (Naumkin et al, 2004).

The Levoberezhnaya Artificial Cave (Left Bank Artificial Cave) is located in Leningrad region, at a distance of 40 $\mathrm{km}$ from St. Petersburg on the territory of the Sablinsky state complex natural monument. The cave represents an ancient excavation of $5.5 \mathrm{~km}$, where the mining of quartzose sandstone began about 150 years ago for the glass industry. Inside the cave there are three lakes, a stream, and numerous landslide halls. Sablinsky State Complex was established in 1976, although it was not properly protected, which inevitably lead to its degradation. In 1992, driven by a public initiative among speleologists, geologists, and ecologists, the authorities of the Leningradskaya Region created 


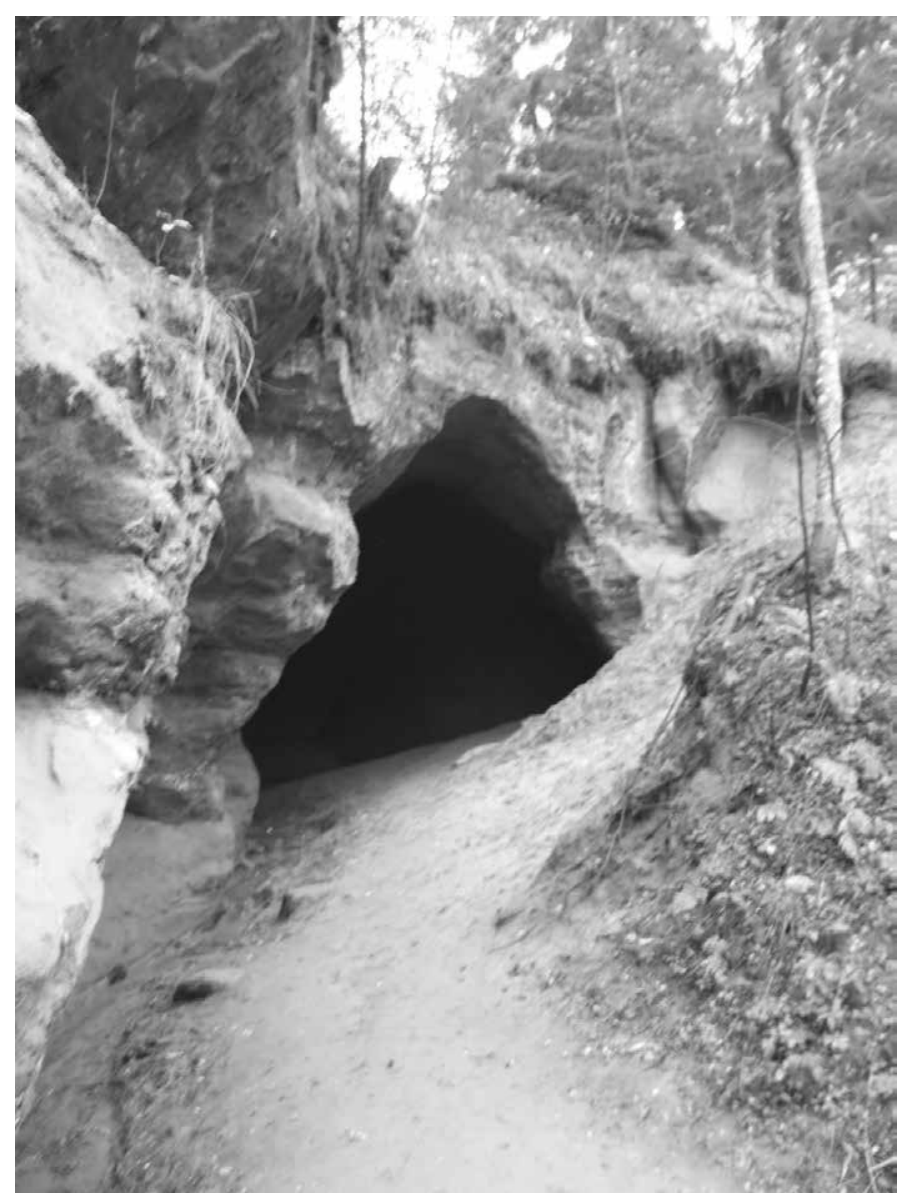

Figure 2. "Svyataya" Cave in Rozhdestveno, located on the tributary of River Oredezh. A rare case of pseudo karst grotto developed as a result of Devonian sandstone erosion and suffusion. the Sablinsky Nature Preservation Excursion and Tourist Center. The work was initiated and supervised by Yu. S. Lyakhnitsky. All tour guides working in the cave use flashlights; however, this weak-working light compromises tourist's safety. To preserve the cave and guarantee safety of the visitors, the hydrologic and microclimatic environment of the cave is carefully monitored and supported.

There are Paleolithic painting exhibits from Kapovaya Cave, model site of the Stone Age man sculpture composition, demonstrating a process of sandstone mining and mineralogical mining. In October 2005, one of the cave rooms was turned into an underground chapel of St. Nicholas the Wonderworker. On religious holidays the church priests hold religious services in this chapel. There was also a primary reconstruction of the surface trail, especially limestone staircases constructed in the steep, canyon paths, which caused ecological excursion trails to be broken. At the entrance to the cave next to the gatehouse, there is a display of ancient animals: trilobite, or thoceratites, ammonite, guard fish, dinosaurs, and mammoth. Large concrete sculptures highlight minor details of the anatomy of these ancient animals to create the picture of fauna evolution on our planet. The natural monument annually accommodates more than 40,000 people, mainly school children. Thus, this self-supporting economic plan allows the people involved both to educate the public and protect the nature complex, preserving the resident bat population.

Pyatigorsky Proval mine is located within the boundaries of Pyatigorsk city (Stavropol Territory), on the southeast shoulder of Mashuk Mountain (Dublyansky, 2008). The mine was mentioned in the novel Knyazhna Mary by the famous Russian writer and poet M. Yu. Lermontov. People used to believe in the healing properties of underground waters and descended to the underground lake, which contains hydrogen sulfide. Mr. Lermontov was one of the first who volunteered to experiment with this theory. In 1858, a horizontal $43.8 \mathrm{~m}$ long tunnel was built into the cave, which made the underground lake accessible to visitors (Maksimovich, 1980).

Another cave, called Bolshaya Azishkaya, is located in Krasnodarsky Territory in the southern part of the Azish-Tau Mountain chain (next to Lagonagsky highland) at a height of 1,600 m above sea level (Samoilenko, 2001). According to B.R. Mavlyudov (2002), the foot traffic varies from 5,000-7,000 people per year. The cave is equipped with electric lighting, metal passageways, and staircases. Initially, the cave was lit by filament lamps that are now being replaced by light-emitting diodes (LEDs). The trail has been functioning since 1989. S. P. Lozovoj in his book, Lagonar Upland, describes the terrible condition of the cave, resulting from its uncontrolled visitation before security provisions and regulated tourist application. "The cave was littered with broken glass, trash, bottles, with damaged stalactites and stalagmites. Over 1,000 dripstones were destroyed." The situation is currently improving. New passageways and staircases have been constructed. Unfortunately, the choice of construction material (metal) was not properly selected. In the course of time, the metal passageways will become unfit for use. They should be replaced with corrosion resistant materials.

As an example of a positive geological heritage preservation story, we may refer to the project aimed at preserving the unique East European Paleolithic paintings in Karpovaya Cave (Shulgan-Tash) in Bashkortostan. It is located on the Belaya (White) River, in the National Park Shulgan-Tash (Lyakhnitsky and Chuiko, 1999). The site is a complex natural monument of world value, the only cave in the Russian Federation that still contains various ancient paintings in relatively good condition. The scientific estimate for the age of these paintings is greater than 17,000 years. In the near past, the cave was visited by tourists, who chose their own unequipped trails to see the paintings. Shulgan-Tash Cave is one of the oldest excursion caves in Russia. The first tourist visits date to the end of $19^{\text {th }}$ century (Kudryashov, 1977, Kichaeva, 2004). 
In 1959, the Natural Park zoologist, A.V. Ryumin, discovered the Late Paleolithic-age cave paintings. As a result of his discovery, the cave instantly became the focus of tourist and scientist's attention on a national and international level. Soon after the discovery and after the spread of the legend on the healing qualities of underground waters and clay, a large number of sick people from all over the former Soviet Union began coming to Shulgan-Tash. In 1967, a new tourist itinerary, No. 57, was launched on the Belaya River that included a visit to the cave. As a result, the anthropogenic impact on the site has significantly increased. I.K Kudryashov provides a description of the unsanitary condition of the cave at the time it was first inspected during the summer of 1977: "Here and there you can see different items left by the sick people: glass jars, bottles, wood pallets, paper, left-over food. In some places it is hard to breathe due to unpleasant odor."

Today, due to the efforts of the Ministry of Culture and National Policy of Bashkortostan and with participation of experts from A. P. Karpinsky All-Russian Institute of Geological Research and the Russian Geographical Society, it was possible to develop a local tour that included visiting a small part of the cave close to the entrance, thus limiting access to authentic paintings located deep inside the cave. Tourists enjoy numerous copies of ancient paintings, a huge Main Gallery, and an entrance grotto called "Portal." Currently there is a precisely careful and scientifically well-grounded design plan for a second tourist itinerary that involves a vertical aspect in addition to the horizontal tour. Visitors will be able to come up to the intermediary terrace of the gallery and enjoy a view of the entrance to the cave from above, which is meant to enhance the emotional impact of the visit. The concept of the first regulated itinerary was approved

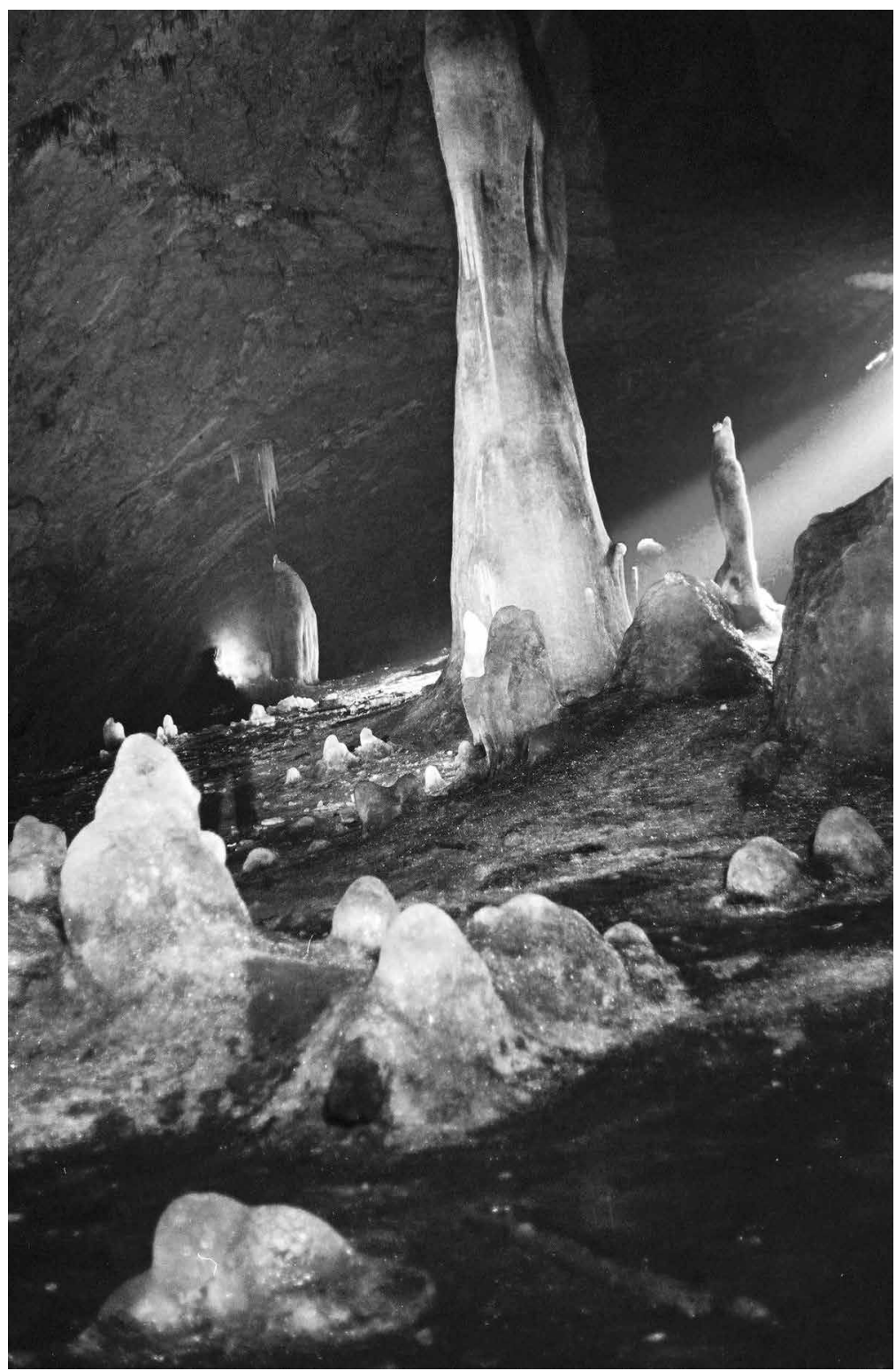

Figure 3. Askynskaya Ice Cave in Bashkortostan. Longstanding ice stalagmites and stalagnates are preserved due to microclimate of the cave. by French experts who visited the cave in 2004. Unfortunately, a few paintings were destroyed by the incoming water. Consequently, new measures have been taken to correct the hydrological regime and microclimate of the cave. It is also planned to restore and provide better security for the paintings. Beside the actions already carried out, there is a plan to create a contemporary Historical and Archaeological Landscape and a Speleological, Cultural and Educational Center dedicated to this unique monument of natural and cultural heritage.

We are justified to state that implementing this project will become a very valuable contribution to protecting natural monuments in the Russian Federation. Thus, using systematic research, regular monitoring, and careful implementation of a short tourist trail, it was possible to save the ancient paintings and Karpovaya Cave itself.

Generally speaking, it is important to reiterate that even sites that are specified as nature preserves are not properly guarded, usually understaffed, and lack proper management. The status of specially protected natural areas and the implementing documents alone cannot replace actual protection and security on site. In this respect, we have to admit that mass violations of the security regime are done by both general public and state authorities. In practice, there is a huge number of examples of natural monument degradation that was the result of such an irresponsible attitude. Even with all these negative tendencies occurring, it is still possible to improve the situation. Back in the 1990s, Yu. S. Lyakhnitsky suggested creating a nature preserve and tourist center, a natural museum based on a self-supporting financial plan (Lyakhnitsky, 2002). However, there is a great number of organizational, legal, and financial challenges to establishing such a center. The initial stage should be supported by the state. The Sablinsky 


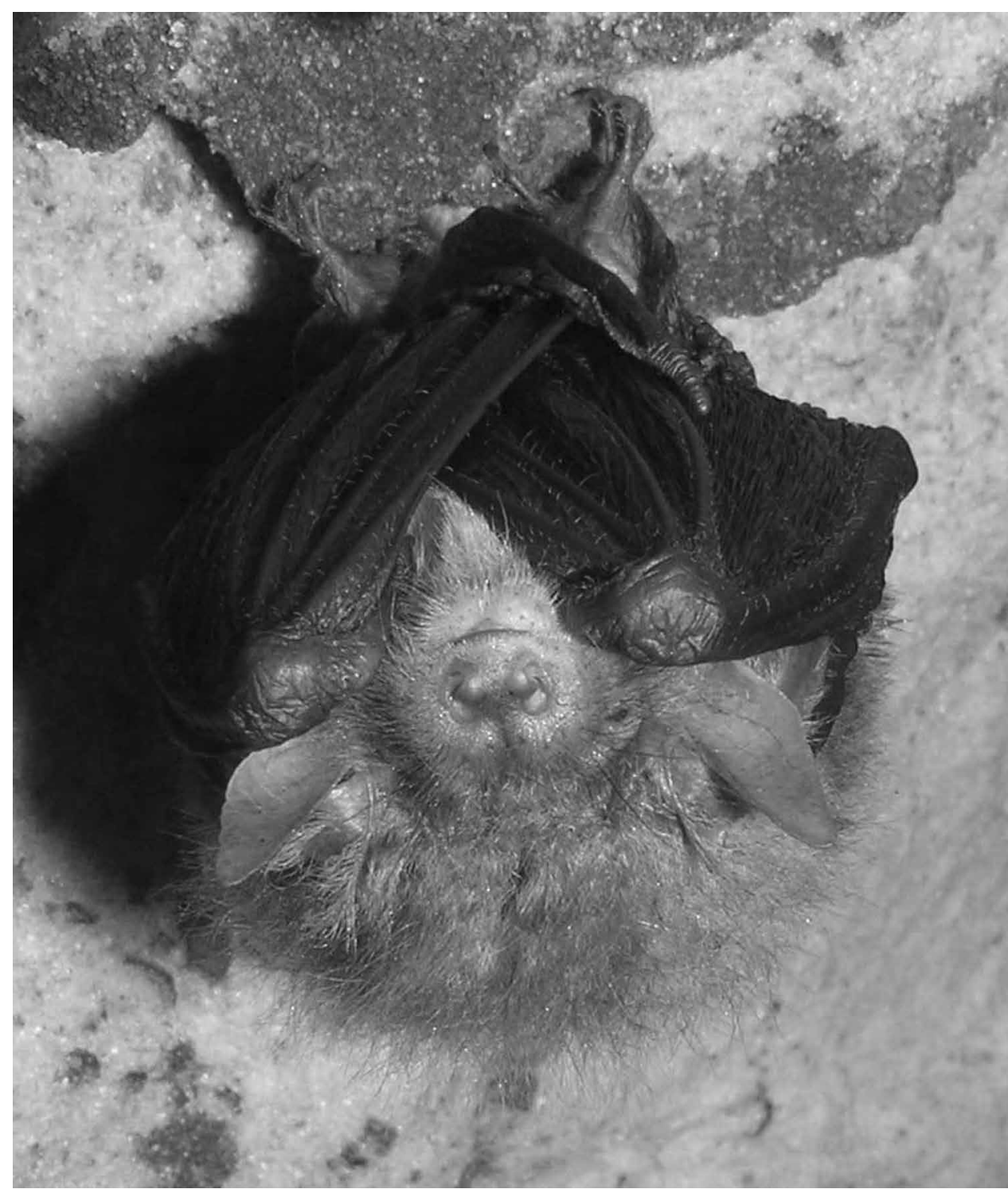

Figure 4. Long-eared bat wintering in Levoberezhnaya Cave. The adopted cave protection and excursion practice does not interfere with the natural wintering of chiropterous animals. natural monument was selected as the first such experimental site.

Sablinsky Nature Preserve and Tourist Center was created within the existing legislation and has been successfully functioning for more than 20 years. During this period, it was visited by a 100,000 school students and families. For most visitors it was a unique experience that allowed individuals to discover the beauty of nature, geology, ecology, and speleology. The educational value of a site visit is considerably more effective than the museum and classroom experience alone.

\section{Methods}

The methods applied can be classified into geological and social-economic. The first group of methods is aimed at doing baseline research of the future tourist destination. Thus, special attention should be paid to measures for preserving the Paleolithic paintings under conditions of increased, regulated excursion and tourist activity that would occur with an improved and updated tourist itinerary.

To achieve these goals, it is necessary to conduct complex monitoring procedures using hydrologic, hydro-chemical, gas, geo-ecological and microclimatic studies (temperature, humidity, airflow, condensation, heat and mass transfer) to develop and implement measures with the purpose of creating favorable, microclimatic conditions.

The second group of methods is concerned with research into operational conditions of the future tourist cluster, created for the specially, protected natural area (i.e., the cave). Systematic methods and comparative analysis, supported by statistical methods, are needed to identify the contemporary conditions and predict the impact to the local economy by development of the area under study. Methods of evaluation and cluster analyses by experts make it possible to design a business model for development of the future tourist cluster. Application of in-depth interviews and other social and psychological examination methods are necessary to monitor public opinion and constructively communicate with the local community, which is an essential element of any tourist cluster.

\section{Results}

The experience gained and the material collected makes it possible to address a very important challenge: to design nature preserve excursion and tourist centers taking into consideration the development of infrastructure to support visitation of complex natural sites. We would suggest using the concept of regulated use of natural heritage sites developed by Yu. S. Lyakhnitsky when establishing a regional tourist cluster. Taking into consideration the special importance of a natural site should be the foundation of the tourist product at the initial stage of development with the express purpose of preserving the natural site. 
Yu. S. Lyakhnitsky suggests establishing a monitored and regulated nature preserve and tourist center on the territory of a specially protected natural area or cave complex. The main operational principals of this center are as follows:

1. Design a research-based professional plan that would rely on procedural rules. Research should include the following:

- Cartographic work;

- Detailed geological mapping of the cave and surrounding locality (maps, plans and profiles);

- Mining and engineering research of the cave structure, to identify trouble areas for the possibility of rock slides; develop measures to strengthen those areas and select safe trail routes;

- Hydro-chemical research to check natural water levels aggressively; pollution, contamination, etc.

- Radiation and radon research, necessary to provide tourist and staff safety;

- Gas monitoring for the contents of $\mathrm{CO}^{2}, \mathrm{CO}$, methane, and other gases in the cave.

2. Nature preserve excursion and tourist organization should be functioning in agreement with the subject of the Russian Federation (territory or the republic). In this respect, the expertise

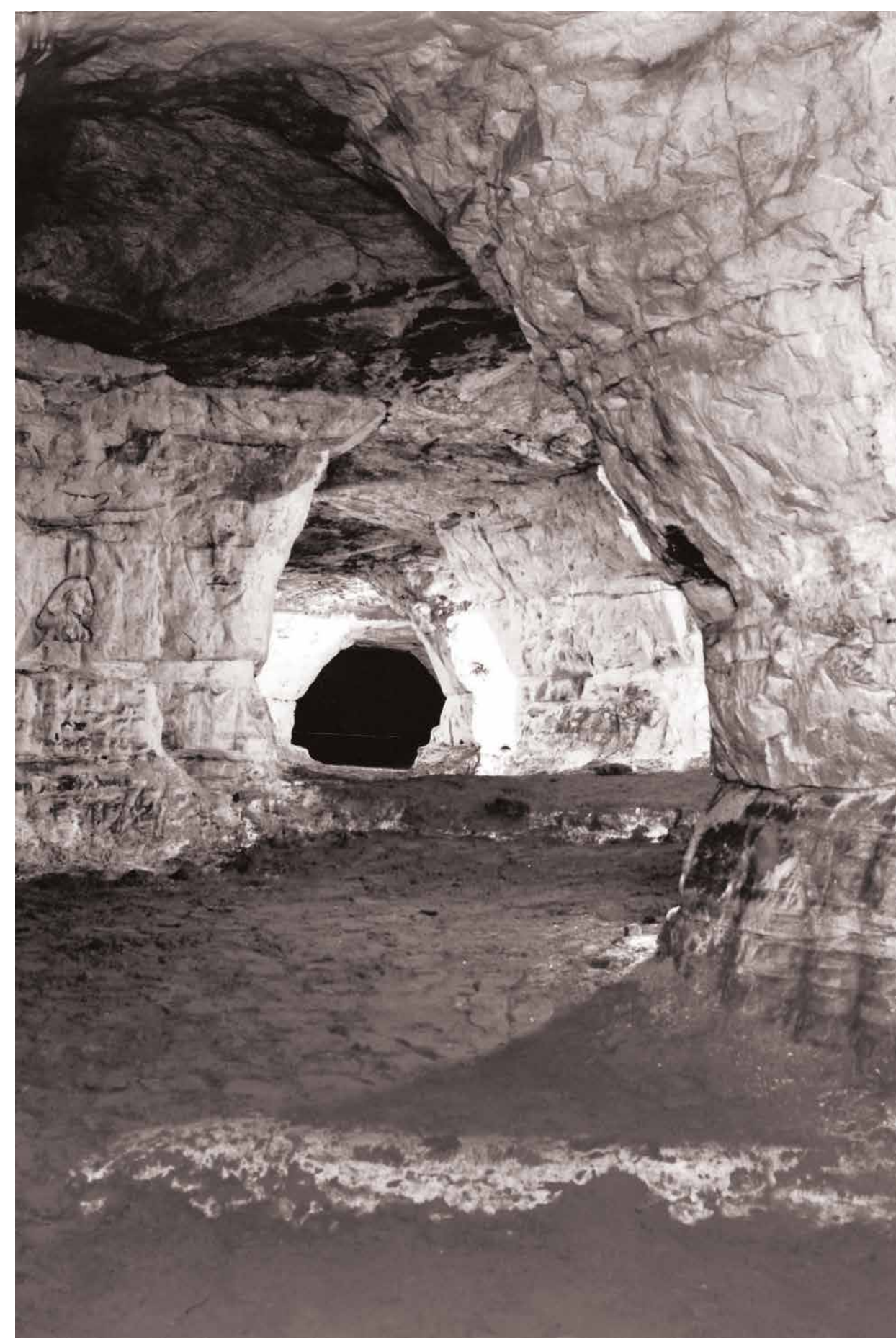

Figure 5. Labyrinth of Levberezhnaya Cave. The cave walls consist of the white, Cambrian "glass" sandstones of Sablinskaya series; the cave roofs consist of Ordovician ferruginous, cross-stratified sandstone. of staff involved is very important: paleontologists should be responsible for the fossil fauna and speleologists should be responsible for the caves. Should a commercial company be involved in tourist use of the cave, it should be obliged to make agreements with professional scientists to develop reasonable projects and monitor the environmental conditions of the site.

3. Financial self-support of the site or minimization of costs. The efforts of companies to develop the cave as a tourist attraction should be based on the principle of self-funding.

4. Proper zoning of the cave, allotting areas for different use and degree of protection, should include the following: reserved, unattended, tourist and recreational areas. To be properly preserved and protected, tourist and 


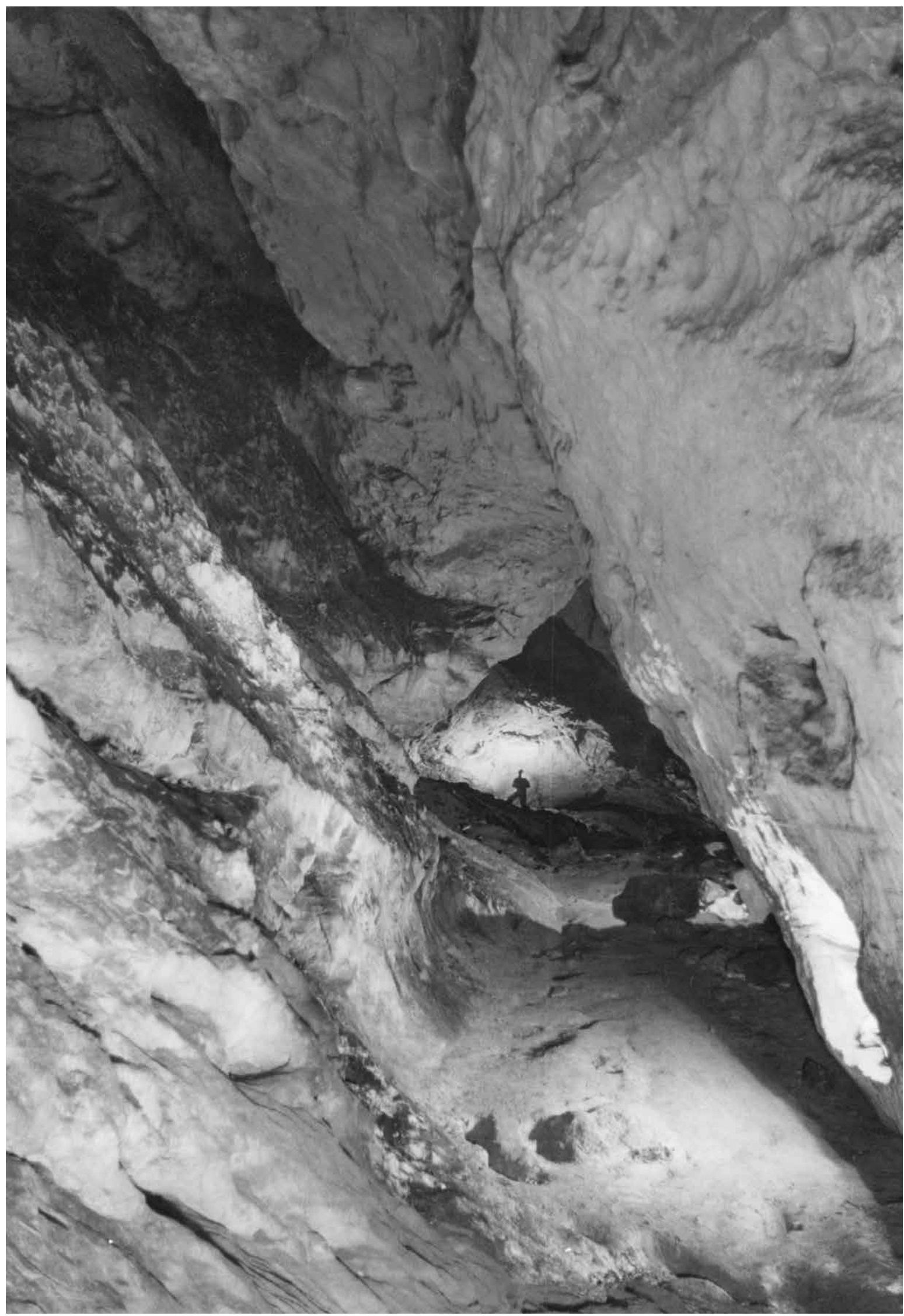

Figure 6. The first gallery of the Kapovaya Cave as an example of large, underground canyon in carbonic limestone. Figures of people can hardly be seen in the huge cavern. 
recreational areas should be smaller in size in comparison to the total size of the cave. However, this can be achieved only in large cave complexes. Small caves (in terms of volume and chambers) can be visited by small, guided groups or individual tourists without establishing tourist complexes around them. Nevertheless, small caves also require regulated tourist use.

5. Distribution of tourist impacts on a specially equipped excursion, environmental, or recreational itineraries (i.e., environmental excursion trails).

6. Creating properly managed tourist areas with displays. Limitation of excursions in accordance with the standards of anthropogenic impacts and continuous monitoring.

7. Application of nature preserve's geo-ecological and educational principles when carrying out research activities in caves. Complex program development aimed at protection and use of variable tourist itineraries. "Horror" caves might improperly educate the youth, and restaurants located inside caves will pollute the environment, causing harm to the natural cave processes. This kind of use inevitably leads to degradation of the cave environment and deprives the public of a natural experience.

8. Tourist infrastructure and service industry facilities should be located in adjacent or urbanized areas.

9. Minimized administrative staff.

10. Organization and coordination of associated advertising, educational activities, and souvenir and printed material emphasizing selling points.

The points mentioned above suggests the necessity of establishing a special unit that would monitor natural, geological monuments with caves. This state unit would take responsibility for regulating protection and use of natural, geological monuments (caves) with Research and Development Centers of the Ministry of Culture located in the subjects of the Russian Federation.

The authors suggest establishing a tourist cave cluster of natural geological monuments. Nature preserve and tourist centers described by Yu. V. Lyakhnitsky $(2002,2006)$ can be taken as the basis of M. Porter's "root" organization. Right now, a contemporary nature preserve and tourist center is being established based on Kapovaya Cave. The status of this object is the Federal Museum Reserve. In order to monitor the condition of the natural monument and its proper protection, it is necessary to have continuous speleological, geological, and ecological monitoring.

When establishing a tourist cluster, where the nature preserve and tourist center act as the tourist attracting component, other commercial and non-commercial organizations are interconnected. We refer to commercial organizations as those providing accommodation and catering services. However, it should be taken into consideration that their location should not degrade the cave complex, i.e., tourist infrastructure should be located at a short, but reasonable,

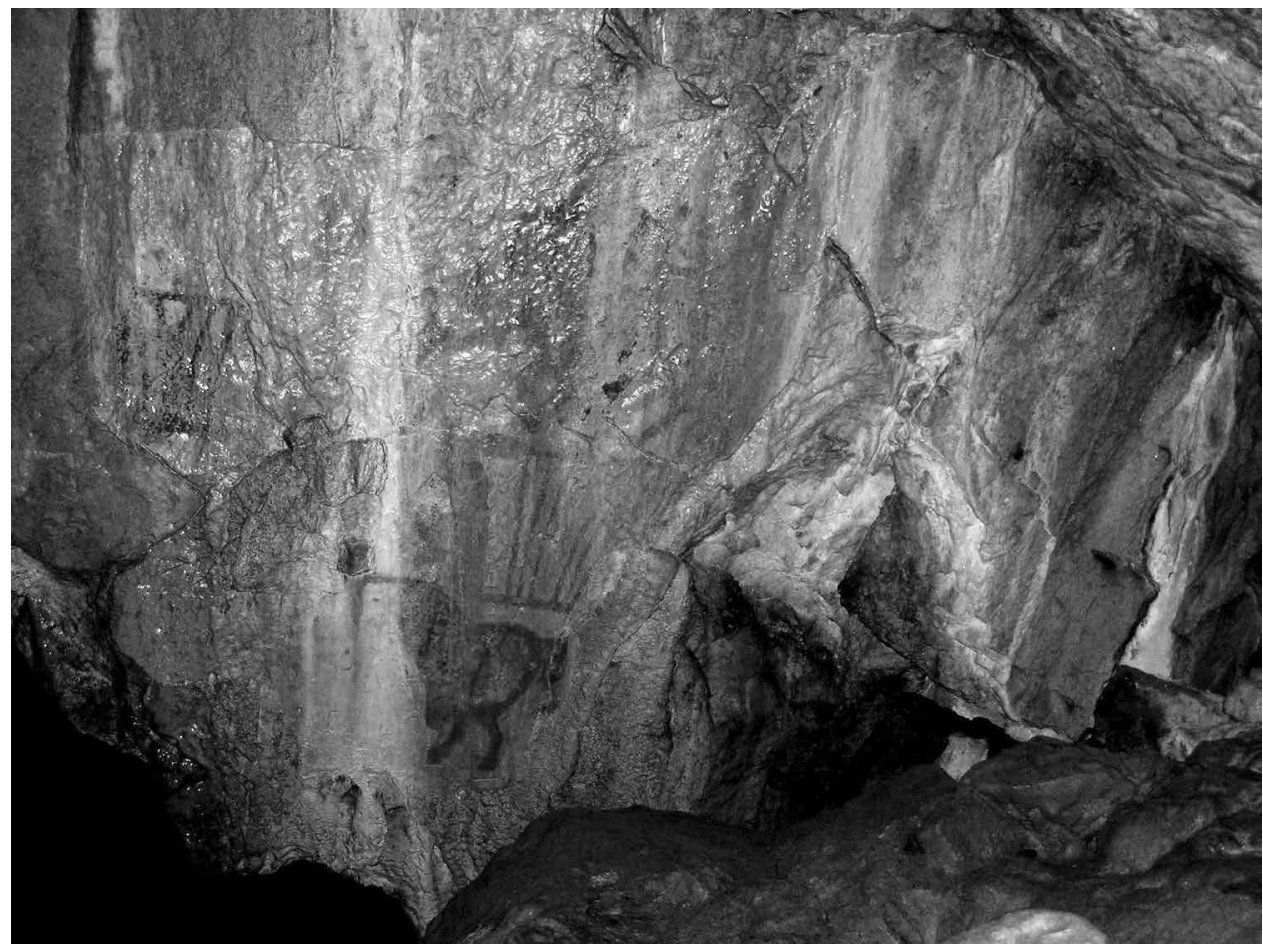

Figure 7. Paleolithic composition "Horses of the Chaos Hall" as an example of the Paleolithic art unique for eastern Europe. In the picture, we can see two, semi-abstract horses and an abstract symbol typical for the Karpovaya Cave-a kind of trapeze. distance from the site (this does not apply to bio-toilets, that should be at a walking distance from the tourist itinerary or trail, but not cause pollution to the immediate environment). Souvenir and other types of shops (jewelry, arts and crafts, local products) connected with the complex should be properly located. This allows more stakeholders to be included in the social and economic process, and gain their loyalty to the growing number of tourists, which will keep their interest in the end result. On the other hand, this aspect significantly increases the net profit margin of the project, and provides a positive feedback effect.

The role of non-commercial entities is also very important. These include various non-profit organizations, such as educational, or social and rehabilitation services. The impact of these organizations 
is hard to overestimate, especially in the low, populated regions, as they exert a strong, positive (or negative) influence on the public opinion.

Tourist clusters in the Russian Federation cannot exist without the governmental support, which first requires adoption of legislative and normative acts, that would regulate the operation of nature preserve and tourist centers, or the whole tourist cluster of a region.

In this respect, we will refer to the Sablinsky nature monument case study. At the beginning of the 1990s, when the western countries were still discussing the "geopark" concept, a group of St. Petersburg scientists, supervised by Yu. S. Lyakhnitsky, took some practical actions to save the Sablinsky nature monument. The area received status as a Nature Monument in 1976, but it was not properly managed or protected at the time, which led to its degradation. The area surrounding the specially protected, natural area was built-up; it contained a lot of waste deposits, the caves collapsed, and others were occupied by trouble-makers-religious fanatics and drug addicts; making it was dangerous to organize guided tours there. The situation is quite different today. Sablinsky Complex Nature Monument is one of the most valuable monuments in the North-West of Russia. It is located $40 \mathrm{kms}$ from St. Petersburg. There are 14 artificial caves (former mine openings significantly altered by natural processes), two waterfalls, the Sablinka and Tosna river valleys, paleontological and mineralogical objects, mineral sources and other tourist attractions connected with the history and culture of the Russian Federation. In 1992, the work of creating Sablinsky Nature Protection Tourist Center was initiated by the public, and the relevant decision was made by the authorities of the Leningradskaya region. The key concept of the decision is organization of the actual monitoring and protection of the specially-protected, natural area using the resources from regulated, tourist excursion activity. The project was approved and received the funding for implementation. Thus, the process of regulated monument development began.

In Levoberezhnaya Cave, there was an equipped underground tourist trail that included strengthening unstable areas, concrete casing of entrance headwalls, regulation of hydrological and microclimatic regimes, removing a tourist trail, and mounting protective screens in the most valuable parts of the monument.

To control and protect the monument, a public, non-commercial organization was established. It included specialists from the fields of speleology, geology, ecology, tourism, and cultural professionals. Nowadays, Levoberezhnaya Cave is properly supervised and guarded around-the-clock; the adjoining area is regularly patrolled; there are around-theseason tour itineraries (a few options). Tourists can choose bus or walking tours, speleological hiking trips that include boating on the underground lakes, etc. In addition to the cave, visitors have the opportunity to enjoy two canyon-shaped river valleys, waterfalls, picturesque rocks, ferriferous minerals, and sulfurated sources. The area is complemented by unique tourist attractions, i.e. the standing post of Tsar Alexander Nevsky before his famous battle with the Swedes. Premise security is carried out by preserving the existing level of anthropogenic pressure on urbanized areas, without increasing the number of visitors. Specially protected areas are kept free from excessive tourist visits.

In general, the experience gained from establishing Sablinsky Nature Preserve and Tourist Center demonstrates that the selected direction first, improved the condition of the object, and serves both educational and aesthetic purposes, and second, improves the general environmental and social situation in the region. In fact, Sablinsky represents the first "geological park" that is much spoken about, but very little is being done to put these ideas into practice. Thus, we have to stress that the center was established within the current legislation and keeps functioning despite the currently emerging challenges. For the past year it has become a very popular visiting site for school students, families, and people of different ages and professions. It is especially valuable that the largest visiting cohort are young people who realize the beauty of the nature, geology, ecology, and speleology after coming to the place.

\section{Discussion}

It is evident that the problems discussed in this paper, even though the reasons are apparent on the surface, do not have easy solutions. We identified the major obstacles hindering the implementation of simple and efficient measures, leading to establishment of nature preserve tourist centers and tourist clusters around cave complexes, and their successful functioning and reliable protection. These are as follows:

1. Lack or absence of initial financing from the state budget or nature protection authorities.

2. Absence of real state nature protection policy in the issues of establishment of nature preserve tourist centers and tourist clusters.

3. Legal obstacles impeding establishment of new, specially-protected nature areas. Position of local authorities that prioritizes immediate profit to environmental processes by selling forest resources, and lending parts of specially-protected areas by breaking the specific character of their use.

4. Passive position of scientists, lack of self-confidence, that they can independently organize nature preserve tourist centers, and corruption on different levels of power from municipal to the federal levels.

5. Absence of generally-accepted federal, scientific and methodological norms of use and protection of the objects of natural and, especially, geological heritage. The municipal and regional committees of nature manage- 
ment experience lack of the legal framework; the civil servants have nothing to rely on in their everyday work with specially-protected nature areas.

6. Insufficient local public awareness efforts on the value of nature preserve tourist center and tourist cluster development. No opportunities for local initiatives to manifest on the levels of legislation and finance.

Nevertheless, certain positive examples make us believe that the solution to this problem is still possible.

\section{Conclusion}

There are noticeable, positive tendencies in protection and use of natural monuments. However, for successful development of this process, and to save the geological heritage of Russia, it is necessary to activate state support. The strategy of preserving Russia's natural heritage is aimed at implementing the concept of regulated use of natural sites, in developing research and methodological directives on the state level, and at least minimum funding of the process of nature preserve tourist centers and tourism clusters establishment, while the tactics are to activate practical work on a regional level. The driving force behind the process are scientists, on the one hand, and nature preserve state authorities, on the other. It is also necessary to keep in mind that natural monuments, representing aesthetic and intellectually important elements of the landscape, exert an important emotional and educational influence on children and young people, and therefore, are ethnically formative and supportive factors. The concept of providing a reliable security of natural geological monuments, using the funds obtained from regulated tourist activity, on condition of professional approach and localization of anthropogenic pressure, is justified. It can act as the basis for saving the natural objects of the Russian Federation. Establishing a tourism complex in the area on the basis of caves raises local tourist appeal. Additionally, it can help with overcoming bureaucratic obstacles in development of the tourist potential of caves.

\section{Acknowledgements}

The research was supported by the Ministry of Education and Science of the Russian Federation: "Social and cultural modernization resources used for efficiency evaluation of strategic programs of spatial development of national tourism."

\section{References}

Aleksandrova, A.Yu., 2007, Tourism clusters: contents, boarders, operational mechanism. Contemporary problems of service and tourism [translated from Turistskie klastery: soderzhanie, granitsy, mekhanizm funktsionirovaniya, Sovremennye problemy servisa i turizma, 2007], n. 1, p. $51-61$.

Bartoli, Zh.P., 2003, Condition and development of excursion caves and their protection as the common heritage, Kungur Ice Cave. Three hundred years of research and tourism activity [translated from Sostoyanie i razvitie ekskursionnykh peshcher i okhrana ikh kak obshchestvennogo naslediya, Kungurskaya Ledyanaya peshchera. 300 let nauchnoy i turisticheskoy deyatel'nosti. Kungur, 2003], Kungur, 2003 , p. 41.

Dublyanskiy, V.N., 1978, The problems of contemporary speleology, Research of karst caves aimed at converting them into tourist attractions. Proceedings of All-Soviet Union meeting [translated from Problemy inzhenernoy speleologii. Issledovanie karstovykh peshcher $v$ tselyakh ispol'zovaniya ikh v kachestve ekskursionnykh ob"ektov. Materialy Vsesoyuznogo soveshchaniya. Tbilisi, 1978.]: Tbilisi p. 14-22.

Dublyanskiy, V.N., 1990, The problem of rational management and protection of geological environment of Crimea and adjacent regions [translated from Problema ratsional'nogo ispol'zovaniya i okhrany geologicheskoy sredy Kryma i prilezhashchikh rayonov. Kiev, 1990$]$ : Kiev, p. 48.

Dublyanskiy, V.N., Dublyanskaya, G.N., 2004, Karst Science. [translated from Karstovedenie. Perm', 2004.]: Perm, 2004. p. 306.

Dublyanskiy, V.N., 2008, Regional karst science, Publishing House of Perm State University [Karstovedenie. CH. 2. Regional'noe karstovedenie, Tipografiya Permskogo gosudarstvennogo universiteta. Perm', 2008], Perm.

Federal Target programme "Domestic and inbound tourism development in the Russian Federation (2011-2018)" -Approved by the governmental Decree from 2.08.2011- Moscow, 2011, [translated from FTSP Razvitie vnutrennego i v"ezdnogo turizma v RF (2011 - 2018 gg.). - Utverzhdena Postanovleniem pravitel'stva RF to 2.08.2011. Moskva, 2011].

Illarionov, A.E. Strategic clusters in municipal economics., 2008, [translated from Strategicheskie klastery v munitsipal'noy ekonomike]: http:/l journal.vlsu.ru/index.php?id=723 (accessed January, 2010).

Kichaeva, L.A., 2004, Lecture on Shulgan-Tashcave [Lektsiya po peshchere Shul'gan-Tash.-Irgizly, 2004]: Irgizlyi, p. 138.

Kovalev, Yu.P., 2011, Regional tourism clusters and tourism development in Russia. Tourism and regional development: collection of research papers, [translated from Territorial'nye turistskie klastery i razvitie turizma v Rossii,Turizm i regional'noe razvitie: sbornik nauchnykh statey. Smolensk, 2011]: Smolensk, Issue 6, p. 88-93.

Kudryashov, I.K., 1977, Report on complex engineering and speleological mining in Shulgan-Tash (Kapova) Cave for the purpose of amenities provision [translated from Otchet o kompleksnykh inzhenerno-geologicheskikh i speleologicheskikh izyskaniyakh v peshchere SHul'gan-Tash (Kapova) dlya ee blagoustroystva. Tom 1. Ufa, Bashkirskiy gos. un-t, Institut geologii BFAN SSSR, 1977]: Ufa, Bashkir State University, Institute of Geology, BFAN SSSR, 1977, v. 1, p. 13-22.

Kungur Ice Cave; experience of regular observations, 2005, [translated from Kungurskaya Ledyanaya peshchera: opyt rezhimnykh nablyudeniy. Ekaterinburg: UrO RAN]: edited by V. N. Dublyanskiy Yekaterinburg: UrO RAN, p. 376.

Lozovoy, S.P., 1984, Lagonar upland [translated from Lagonakskoe nagor'e, Krasnodarskoe knizhnoe izdatel'stvo. Krasnodar, 1984]: Krasnodar, Krasnodar, $160 \mathrm{p}$.

Lukin, V.S. and Dorofeev, E.P., 1993, Search, filming and improvement works in Kungur Ice Cave [translated from Poiski, s"emka i raboty po blagoustroystvu v Kungurskoy ledyanoy peshchere, sb. Peshchery, Perm', 1993]: Perm, Issue Pescheryi, 1993, p. 156-163.

Lyahnitsky, Yu.S.. and Chuiko, M.A., 1999, Complex research of the Karpovaya Cave [translated from Kompleksnoe issledovanie Kapovoy peshchery. 1999]: Pescheryi, Issue 25/26, p. 21-37.

Lyakhnitsky, Yu.S., 2002, Research and methodological grounds for the protection and use of caves as the monuments of nature: Problems and ecology of cave protection. [translated from Nauchno-metodicheskie osnovy okhrany i ispol'zovaniya peshcher, kak pamyatnikov prirody/Problemy ekologii i okhrany peshcher]: Krasnoyarsk, p. 127-130. 
Lyakhnitsky, YuS., 2002, Shulgantash Kitap Caves [translated from Lyakhnitskiy Yu. S. "Shul'gantash”. "Kitap," Ufa, 2002]: Ufa, p. 200.

Lyakhnitsky, YuS., 2006, The problem of protection and use of the objects of geological heritage as exemplified by the Leningrad Region and other Russian regions, Regional Ecology. Russian Academy of Sciences. No 3-4 (27) [translated from Problema okhrany i ispol'zovaniya ob"ektov geologicheskogo naslediya na primere Leningradskoy oblasti i drugikh regionov Rossii. Regional'naya ekologiya. RAN. n. 3-4 (27) S-Pb. 2006. S.105-,113]: Saint Petersburg, p. 105-113.

Lyakhnitsky, Yu.S., 2006, The problem of protection and use of the objects of geological heritage in Russia [translated from Problema okhrany $\mathrm{i}$ ispol'zovaniya ob"ektov geologicheskogo naslediya Rossii. /Regional'naya geologiya i metallogeniya. n. 29. S-Pb. VSEGEI, 2006.]]: Regional geology and metallogeny, No. 29, Saint Petersburg, VSEGEI, p. 133-148.

Maksimovich G.A., 1963, Basics of karst science. [translated from Osnovy karstovedeniya. T.1 Perm' Kn. Izd.1963.]: Perm, v.1, 444 p.

Maksimovich, G.A., 1980, Tourist caves in the USSR and their visitation, Issue Pescheryi [translated from Turistskie peshchery SSSR i ikh poseshchaemost', sb. Peshchery, Perm', 1980]: Perm, p. 86-96.

Mavlyudov, B.R., 2002, Protection and use of natural caves in Russia, Problems of ecology and cave protection [translated from Okhrana i ispol'zovanie estestvennykh peshcher v Rossii, Problemy ekologii i okhrany peshcher. Krasnoyarsk, 2002]: Krasnoyarsk, p. 118.

Mavlyudov, B.R., 2008, Factors of vulnerability of caves, Problems of ecology and protection of caves [translated from Faktory uyazvimosti peshcher, Problemy ekologii i okhrany peshcher. Krasnoyarsk, 2008]: Krasnoyarsk, p. 5-9.

Mazina, S.E., Severin A.V., 2007, The development of rehabilitation method for underground systems under the impact of anthropogenic transformations as exemplified by Novoafonskaya Cave, Environmental chemistry [translated from Razrabotka metoda reabilitatsii antropogenno-transformirovannykh podzemnykh sistem na primere Novoafonskoy peshchery, Ekologicheskaya khimiya, 16(3). M, 2007]: Moscow, v. 16, no. 3, p. 175-181.

Naumkin, D.V., Sevastyanov, V.M., Lavrov, I.A., 2004, Kungur wildlife area. [translated from Kungurskiy zapovednyy kray. - Perm’, OOO «Raritet-Perm'», 2004]: LLC "Raritet-Perm," 2004. p. 49.

Porter M., 2000, Location, competition, and economic development: local clusters in a global economy: Economic Development Quarterly, v. 14, n. 1, p. 15-34. https://doi.org/10.1177/089124240001400105.

Polukhina, A.N., 2010, Development of management in tourism and hospitality business [translated from Razvitie upravleniya $v$ sfere turizma i gostepriimstva, Yoshkar-Ola: LANFORT, 2010]: Yoshkar-Ola, LANFORT, p. 256.

Polukhina, A.N. and Talalaev, M.V., 2012, Regional tourism: analysis, theory and practice of management [translated from Regional'nyy turizm: analiz, teoriya i praktika upravleniya, Yoshkar-Ola: MarGTU, 2012]: Yoshkar-Ola, MarGTU, p. 188.

Polukhina, A.N. and Talalaev, M.V., 2014, Problems of entrepreneurship development in tourism business in the Russian regions: monograph [translated from Problemy razvitiya predprinimatel'stva v sfere turizma v regionakh Rossii: monografiya,Yoshkar-Ola, PGTU, 2014]: Yoshkar-Ola, PGTU, p. 232.

Rapp V., 1999, Guide on Kungur Ice Cave [translated from Putevoditel' po Kunguru i Ledyanoy peshchere, Perm', izd. «Zvezda», 1999]: Perm, "Zvezda," p. 84.

Rezvan, V.D., 2004, Environmental and legal problems of tourist and excursion use of speleo-resources under new social and economic conditions (as exemplified by the Big Sochi, Karst science,21st century: theoretical and practical importance: Proceedings of the international symposium (25-30 May, 2004) [translated from Ekologo-pravovye problemy turistsko-ekskursionnogo ispol'zovaniya speleoresursov $v$ novykh sotsial'no-ekonomicheskikh usloviyakh (na primere Bol'shogo Sochi), Karstovedenie, XXI vek: teoreticheskoe i prakticheskoe znachenie: Materialy mezhdunarodnogo simpoziuma (25-30 maya 2004, Perm', Rossiya). Perm', 2004]: Perm, p. 370-374.

Samoilenko, A.A., 2001, Guide on Kuban region [translated from Putevoditel' po Kubani. Krasnodar, 2001]: Krasnodar, p. 77.

Shabalina, N.V., 2007, Basics of tourism clustering [translated from Vvedenie v turistskuyu klasterizatsiyu]: http://bzm.su/articles/article-05 (accessed January 2010).

Tsyikin, R.A., 1978, Tourism caves of Krasnoyarsk Region, Research of karst caves in order to use them as tourist destinations [Turistskie peshchery krasnoyarskogo kraya, Issledovanie karstovykh peshcher $v$ tselyakh ispol'zovaniya ikh $v$ kachestve ekskursionnykh ob"ektov. Materialy Vsesoyuznogo soveshchaniya. Tbilisi, 1978 god]: Tbilisi, p. 130-131.

Vahrushev, B.A., Amelichev, G.N., Semenova, E.N., 1999, The Marble Cave, issue Caves [translated from Mramornaya peshchera, sb. Peshchery, Perm', 1999]: Perm, p. 46. 